\title{
HIPERHOMOSISTEINEMIA SEBAGAI RISIKO PENYAKIT JANTUNG KORONER
}

\section{HYPERHOMOCYSTEINEMIA AS A RISK FOR CORONARY HEARTH DISEASE}

\author{
Bambang Irawan*, Moch Sja'bani**, Muhamad Ayus Astoni** \\ *Bagian Kardiologi dan Kedokteran Vaskuler Fakultas Kedokteran Universitas Gadjahmada Yogyakarta \\ ${ }^{* *}$ Bagian IImu Penyakit Dalam Fakultas Kedokteran Universitas Gadjahmada Yogyakarta
}

\begin{abstract}
The elevation of total plasma homocysteine is associated with increase of risk for cardiovascular disease, cerebrovascular disease, and atherothrombosis in peripheral arteries. Several prospective and retrospective studies had conformed the positive association between hyperhomocysteinemia and risk for cardiovascular disease. However, it whether hyperhomocysteinemia is an independent risk factor for cardiovascular disease associated with the others risk factors still become a question. The aim of this study was to identify the association between hyperhomocysteinemia and increased risk for cardiovascular disease. A matched case-control study based on 50 consecutive adult patients aged more than 18 years old who admitted in Dr. Sardjito General Hospital by first acute coronary syndrome. Fifty comparison control subjects were randomly selected age and gender group-matched patients admitted caused by conditions other than cardiovascular disease to the same hospital. Each case was enrolled, and comparison subject was randomly selected. Fasting blood samples for homocysteine were obtained from both groups. Chi square test, McNemar chi square test, and independent $t$ test had been used in univariate analysis. Confounding factors had been analysed using stratification technic (Mantel-Haenszel test) and logistic regression multivariate analysis. Mean age was 61,46 $\pm 10,62$ (case) and 60,88 \pm 10,72 (control) years; $82 \%$ were male (cases and controls). Mean fasting homocysteine levels were significantly higher in cases than in controls $(24,82 \pm 12,69 \mu \mathrm{mol} / \mathrm{L}$ vs $14,74 \pm 5,96 \mu \mathrm{mol} / \mathrm{L}, 95 \% \mathrm{Cl}: 6,23-13,93)$. Compared with the lowest homocysteine tertile, the highest tertile was significantly had higher odds ratio associated with an OR 5,48 (95\% Cl: 2,12-13,12; $p=0,019$ ) for cardiovascular disease. Using McNemar chi square test, the odds ratio was 4,80 (95\% Cl: 2,11-10,85; $p=0,001)$. Using a logistic regression, the odds ratio was 5,67 (95\% Cl: 3,16 - 17,61; $p<$ 0,01). Hyperhomocysteinemia is an indepandent risk factor for coronary hearth disease.
\end{abstract}

Key words : Homocysteine - Risk Factor - Cardiovascular Disease - Case-Control.

\section{PENDAHULUAN}

Penyakit jantung koroner merupakan kelainan yang makin tinggi frekuensinya baik di negara maju maupun negara yang sedang berkembang. Berbagai faktor risiko telah dikenal dan berbagai penelitian telah banyak dilakukan untuk mengungkap terjadinya proses aterosklerosis yang menjadi dasar dari penyakit jantung koroner (1).

Kenaikan kadar lemak didalam darah, penyakit gula, hipertensi, kebiasaan merokok, obesitas, dan hiperhomosisteinemia telah dikenal sebagai faktor risiko terjadinya aterosklerosis tersebut $(2,3)$.

Peningkatan kadar homosistein dalam darah akhirakhir ini telah ditegakkan sebagai faktor risiko independen untuk terjadinya trombosis dan penyakit vaskuler $(4,5)$. Hiperhomosisteinemia ini akan lebih meningkatkan lagi kejadian aterotrombosis vaskuler pada individu dengan

Jurnal Kedokteran Brawijaya, Vol. XXI, No.3, Desember 2005 Korespondensi: Bambang Irawan; Laboratorium Kardiologi dan Kedokteran Vaskuler Universitas Gadjah Mada Yogyakarta; Sekip Utara Yogyakarta faktor risiko yang lain seperti kebiasaan merokok dan hipertensi (6).

Lebih dari 31 penelitian kasus-kontrol dan potong lintang yang melibatkan sekitar 7000 penderita didapatkan hiperhomosisteinemia pada $30 \%$ sampai $90 \%$ penderita aterosklerosis dan berhubungan dengan peningkatan risiko penyakit jantung koroner (7).

Wald et al (1998) telah meneliti 21520 laki-laki dari usia 35 sampai dengan 64 tahun dan didapatkan risiko penyakit jantung koroner pada kelompok homosistein total [tHcy] kuartil tertinggi 2,9 kali lipat dibandingkan dengan kuatil terendah setelah dilakukan penyesuaian terhadap faktor-faktor risisko yang lain (8). Risiko meningkat sebesar $41 \%$ untuk setiap kenaikan konsentrasi tHcy sebesar 5 $\mu \mathrm{mol} / \mathrm{L}$. Pada kelompok yang meninggal oleh sebab penyakit jantung koroner didapatkan kadar tHcy rata-rata $13,1 \mu \mathrm{mol} / \mathrm{L}$ sedangkan pada yang meninggal oleh sebab yang lain $11,8 \mu \mathrm{mol} / \mathrm{L}$.

Prevalensi hiperhomosisteinemia diperkirakan sekitar $5 \%$ pada populasi normal sedangkan pada penderita aterosklerosis sekitar $13-47 \%$ (9). 
Penelitian ini bertujuan untuk mengetahui apakah hiperhomosisteinemia merupakan faktor risiko independen terhadap penyakit jantung koroner.

\section{METODE}

Penelitian ini merupakan penelitian kasus kontrol yang bersifat deskriptif analitik. Teknik pengambilan sampel untuk kelompok kasus dengan cara berurutan yaitu setiap penderita sindroma koroner akut serangan pertama yang dirawat di rumah sakit Sardjito dan memenuhi kriteria terpakai diambil sampel untuk kelompok kasus sampai tercapai jumlah sampel yang ditentukan. Kelompok kontrol ditentukan dengan pemilihan secara acak satu subyek kontrol untuk setiap satu subyek kasus dari penderita bukan penyakit jantung koroner yang dirawat di bagian Penyakit Dalam Rumah Sakit dr. Sardjito yang masuk pada tanggal yang sama dengan subyek kasus. Antara kelompok subyek kasus dengan kelompok subyek kontrol dipadankan jenis kelamin dan usia yang tidak lebih dari 5 tahun selisihnya.

Penderita dengan hiperhomosisteinemia adalah dengan kadar $>15(n=64)$. Kadar tHcy diperiksa dalam keadaan puasa dengan menggunakan teknik high performance liquid chromatography.

Kasus terpakai adalah penderita penyakit jantung koroner yang dirawat dengan sindroma koroner akut untuk pertama kalinya, berumur lebih atau sama dengan 18 tahun dan bersedia ikut dalam penelitian dan dirawat di rumah sakit Sardjito.

Kasus kontrol adalah penderita bukan penyakit jantung koroner dan bukan stroke yang dipadankan menurut usia dan jenis kelamin, tidak ada riwayat penyakit jantung koroner atau stroke sebelumnya dan bersedia ikut dalam penelitian serta dirawat di rumah sakit Sardjito.

Besar sampel ditentukan dengan menggunakan rumus besar sampel untuk matched case-control study (10).

Dimana

$$
\mathbf{M}=\mathrm{m} /\left(\mathrm{p}_{0} q_{1}+\mathrm{p}_{1} q_{0}\right)
$$

$m=\frac{[Z \alpha / 2+Z ß \sqrt{ } P(1-P)]^{2}}{(P-1 / 2)^{2}}$

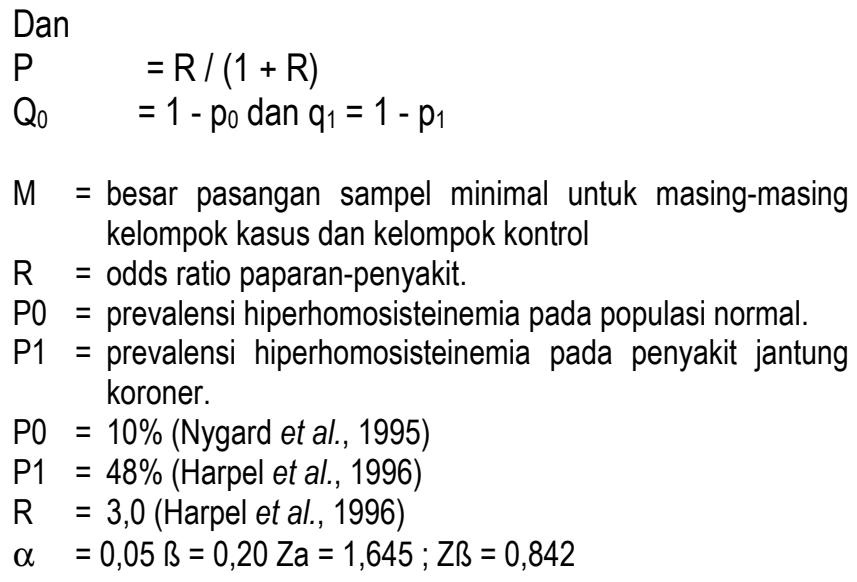

Dari perhitungan, didapatkan nilai $\mathrm{P}=0,75 ; \mathrm{Q} 0=0,9$; $\mathrm{Q} 1=0,52$; dan $\mathrm{m}=22,54$ Dengan memasukkan ke dalam rumus tersebut diatas maka didapatkan perhitungan besar sampel untuk penelitian ini adalah 46,6 untuk masingmasing kelompok. Pada penelitian ini diambil besar sampel 50 untuk masing-masing kelompok.

Variabel bebas yang diukur dalam penelitian ini adalah kadar tHcy, riwayat hipertensi, tekanan darah dan kadar kreatinin pada saat masuk rumah sakit. Variabel tergantung adalah penyakit jantung koroner. Karakteristik subyek meliputi nama, umur, jenis kelamin, alamat dan pekerjaan. Data diambil secara otoanamnesis dan alloanamnesis.

Analisis univariat sebagian besar dengan uji kai kuadrat dan analisis multivariat menggunakan regresi logistik. Semua ukuran risiko [Odd ratio $=\mathrm{OR}$ ] dihitung untuk tingkat kepercayaan 95\% [95\% Cl].

\section{HASIL PENELITIAN}

Hasil penelitian ini terdiri dari analisis deskriptif dan analisis data secara statistik, dan akan disajikan dalam 3 bagian pokok, yaitu karakteristik dasar kelompok kasus dan kelompok kontrol, hasil analisis univariat masing-masing faktor risiko dan hasil analisis multivariat faktor risiko.

Karakteristik Dasar Subyek

Karakteristik dasar subyek kelompok kasus dan kontrol dianalisis secara deskriptif.

Tabel 1. Distribusi Usia dan Jenis Kelamin Penderita Penyakit Jantung Koroner dan Kontrol

\begin{tabular}{ccccc}
\hline \multirow{2}{*}{ Usia(tahun) } & \multicolumn{2}{c}{ Kasus } & \multicolumn{2}{c}{ Kontrol } \\
\cline { 2 - 5 } & Laki-laki(n) & Perempuan(n) & Laki-laki(n) & Perempuan(n) \\
\hline $35-44$ & 2 & 0 & 4 & 0 \\
$45-54$ & 8 & 4 & 7 & 4 \\
$55-64$ & 15 & 3 & 15 & 4 \\
$65-74$ & 10 & 1 & 9 & 1 \\
$\geq 75$ & 6 & 1 & 6 & 0 \\
\hline Total & $41(82 \%)$ & $9(18 \%)$ & $41(82 \%)$ & $9(18 \%)$ \\
\hline Rata-rata Usia & \multicolumn{2}{c}{$61,46 \pm 10,62$} & \multicolumn{2}{c}{$60,88 \pm 10,72$} \\
\hline
\end{tabular}


Sebanyak 100 penderita (penderita rawat inap sejak bulan November 2003 sampai dengan bulan Maret 2004) berpartisipasi dalam penelitian ini, terdiri dari 50 kasus dan 50 kontrol yang dirawat di RSUP Dr. Sardjito Yogyakarta. Kelompok kontrol dipadankan menurut usia dan jenis kelamin dengan kelompok kasus, dimana perbedaan usia antara kasus dan kontrol tidak boleh lebih dari 5 tahun dan berasal dari Rumah Sakit yang sama dengan kasus. Dengan melakukan matched terhadap usia dan jenis kelamin maka distribusi subyek penelitian menurut usia dan jenis kelamin tersebar merata pada kedua kelompok (Tabel 1). Rata-rata usia kedua kelompok adalah sama $(P>0,05)$. Diagnosis pada kelompok kontrol termasuk observasi febris, dispepsia, infeksi saluran kemih, pneumonia, gastroenteritis, low back pain, dan hernia.

Karakteristik dasar kelompok kasus dan kontrol dirangkumkan pada Tabel 2. Prevalensi faktor risiko vaskuler konvensional seperti adanya riwayat hipertensi lebih tinggi pada kelompok kasus (16 orang) dibandingkan dengan kontrol (8 orang) secara statistik perbedaan ini tidak bermakna dengan $p=0,06$. Untuk status merokok lebih tinggi pada kelompok kasus (17 orang) dibandingkan dengan kontrol (5 orang) perbedaan ini secara statistik bermakna dengan $p=0,009$. Status merokok berdasarkan indeks Brinkman (IB) pada kelompok kasus dan kelompok kontrol termasuk dalam IB sedang (200-400). Rata-rata tekanan darah sistolik dan diastolik tidak berbeda bermakna pada kelompok kasus dan kelompok kontrol. Rata-rata kadar gula darah sewaktu lebih tinggi bermakna pada kelompok kasus dibandingkan kelompok kontrol $(138,10 \pm$ $30,15$ vs $121,22 \pm 33,50 ; 95 \% \mathrm{Cl}: 16,64-48,32 ; \mathrm{p}=0,009)$. Rata-rata kadar tHcy puasa lebih tinggi bermakna pada kelompok kasus dibandingkan dengan kelompok kontrol $(24,82 \pm 12,69 \mu \mathrm{mol} / \mathrm{L}$ vs $14,74 \pm 5,96 \mu \mathrm{mol} / \mathrm{L} ; 95 \% \mathrm{Cl}$ : $6,23-13,93 ; p<0,01)$ Sedangkan suatu efek protektif dari $\mathrm{HDL}$ jelas terlihat, rata-rata kadar $\mathrm{HDL}$ lebih tinggi bermakna pada kelompok kontrol ( 49,78 $\pm 11,55 \mathrm{mg} / \mathrm{dl}$ vs $57,26 \pm 16,43 ; 95 \% \mathrm{Cl}:-13,11-1,84 ; p=0,010$,$) .$

Tidak ada perbedaan rata-rata usia, tekanan darah sistolik dan diastolik, kadar ureum, kreatinin, gula darah sewaktu, dan rata-rata kadar profil lipid antara pasienpasien dengan hiperhomosisteinemia dan pasien-pasien yang kadar homosisteinnya normal (Tabel 3).

Tabel 2. Karakteristik Demografi, Faktor Risiko Vaskuler dan Hasil Laboratorium

\begin{tabular}{|c|c|c|c|c|c|}
\hline Variabel & Kasus $(n=50)$ & Kontrol $(n=50)$ & $\mathrm{P}$ & OR 95\% Cl & $95 \% \mathrm{Cl}$ diff of mean \\
\hline $\begin{array}{l}\text { Riwayat / Hipertensi } \\
\text { - Ya } \\
\text { - Tidak }\end{array}$ & $\begin{array}{l}16 \\
34\end{array}$ & $\begin{array}{c}8 \\
42\end{array}$ & 0,061 & $\begin{array}{c}2,47 \\
0,94-6,46\end{array}$ & \\
\hline $\begin{array}{l}\text { Status Merokok } \\
\text { - Perokok } \\
\text { - Bukan perokok }\end{array}$ & $\begin{array}{l}17 \\
33\end{array}$ & $\begin{array}{c}5 \\
45\end{array}$ & 0,009 & $\begin{array}{c}3,78 \\
1,34-10,64\end{array}$ & \\
\hline $\begin{array}{l}\text { TD saat MRS (mmHg) } \\
\text { - Sistolik } \\
\text { - Diatolik }\end{array}$ & $\begin{array}{c}122,02 \pm 26,21 \\
80,24 \pm 18,74,74\end{array}$ & $\begin{array}{l}129,70 \pm 9,55 \\
81,62 \pm 11,55\end{array}$ & $\begin{array}{l}0,10 \\
0,66\end{array}$ & & $\begin{array}{c}-16,86-1,50 \\
-7,56-4,80\end{array}$ \\
\hline Mean tHcy(umol/L) & $24,82 \pm 12,69$ & $14,74 \pm 5,96$ & $<0,01$ & & $6,23-13,93$ \\
\hline Trigliserid,mg/dl & $141,12 \pm 62,4$ & $143,44 \pm 40,10$ & 0,826 & & $-23,15-8,51$ \\
\hline Cholesterol total,mg/dl & $198,88 \pm 44,95$ & $182,95 \pm 44,73$ & 0.079 & & $-1,87-33,72$ \\
\hline $\mathrm{HDL}, \mathrm{mg} / \mathrm{dl}$ & $49,78 \pm 11,55$ & $57,26 \pm 16,43$ & 0,010 & & $-13,11-1.84$ \\
\hline $\mathrm{LDL}, \mathrm{mg} / \mathrm{dl}$ & $114,30 \pm 35,36$ & $114,28 \pm 34,56$ & 0,998 & & $-13,86-3,89$ \\
\hline Kreatinin, mg/dl & $1,31 \pm 0,55$ & $1,10 \pm 0,39$ & 0,072 & & $2,41-0,40$ \\
\hline GDR, mg/dl & $138,10 \pm 30,15$ & $121,22 \pm 33,50$ & 0,009 & & $16,64-48,32$ \\
\hline
\end{tabular}

Keterangan:

TD : Tekanan Darah

MRS: Masuk Rumah Sakit

GDR: Gula Darah up Random 
Tabel 3. Karakteristik Subyek Menurut Kadar Homosistein Total Plasma

\begin{tabular}{lccc}
\hline \multirow{2}{*}{ Variabel (rata-rata \pm SD) } & \multicolumn{3}{c}{ Kadar Homostatin Total plasma $(\mu \mathrm{mo} / \mathrm{L})$} \\
\cline { 2 - 4 } & Hiperhomosisteinemia $>15(\mathrm{n}=64)$ & Normal $\leq 15(\mathrm{n}=36)$ & $\mathrm{p}$ \\
\hline Umur, tahun & $61,02 \pm 10,41$ & $61,44 \pm 11,14$ & 0,847 \\
\hline Tekanan darah sistolik, $\mathrm{mmHg}$ & $124,06 \pm 24,88$ & $129 \pm 20,21$ & 0,307 \\
\hline Tekanan darah diastolik, $\mathrm{mmHg}$ & $81,11 \pm 17,25$ & $80,61 \pm 12,01$ & 0,878 \\
\hline Kolesterol, $\mathrm{mg} / \mathrm{dl}$ & $195,47 \pm 42,50$ & $182,83 \pm 49,44$ & 0,182 \\
\hline Trigliserida, $\mathrm{mg} / \mathrm{dl}$ & $141,94 \pm 55,09$ & $142,87 \pm 47,44$ & 0,931 \\
\hline $\mathrm{HDL}, \mathrm{mg} / \mathrm{dl}$ & $52,15 \pm 11,78$ & $55,97 \pm 18,58$ & 0,211 \\
\hline LDL, $\mathrm{mg} / \mathrm{dl}$ & $114,73 \pm 37,26$ & $113,50 \pm 30,37$ & 0,866 \\
\hline BUN, mg/dl & $20,43 \pm 14,41$ & $17,76 \pm 8,96$ & 0,317 \\
\hline Kreatinin, mg/dl & $1,26 \pm 0,51$ & $1,11 \pm 0,41$ & 0,124 \\
\hline Gula darah sewaktu, $\mathrm{mg} / \mathrm{dl}$ & $132,25 \pm 30,01$ & $125,06 \pm 37,32$ & 0,295 \\
\hline
\end{tabular}

Tidak ada perbedaan bermakna secara statistik ratarata kadar tHcy antara laki-laki dan perempuan pada kedua kelompok, meskipun rata-rata kadar tHcy pada laki-laki kelompok kasus lebih tinggi dibanding perempuan, $d$ an rata-rata kadar tHcy pada perempuan kelompok kontrol lebih tinggi dibanding laki-laki (Tabel 4).

Tabel 4. Rata-rata Kadar Homosistein Berdasarkan Jenis Kelamin

\begin{tabular}{lcc}
\hline Jenis kelamin & \multicolumn{2}{c}{ Rata-rata Kadar Homostatin $(\mu \mathrm{mol} / \mathrm{L})$} \\
\cline { 2 - 3 } & Kasus & Kontrol \\
\hline Laki-laki & $25,12 \pm 13,09$ & $14,18 \pm 5,10$ \\
\hline perempuan & $23,47 \pm 11,32$ & $17,29 \pm 5,13$ \\
\hline$p$ & 0,728 & 0,105 \\
\hline
\end{tabular}

Tabel 5. Odds Ratio Faktor Risiko Penyakit Jantung Koroner

\begin{tabular}{clccc}
\hline No & \multicolumn{1}{c}{ Faktor Risiko } & OR & $95 \%$ Cl of OR & $\mathrm{P}$ \\
\hline 1 & Riwayat Hipertensi & 2,47 & $0,94-6,46$ & 0,061 \\
\hline 2 & Status merokok & 3,78 & $1,34-10,63$ & 0,009 \\
\hline 3 & Hiperkolesterolemia & 1,00 & $0,44-2,26$ & 1,00 \\
\hline 4 & HDL rendah & 3,26 & $1,01-5,05$ & 0,045 \\
\hline 5 & Hiperhomosisteinemia & 5,06 & $2,15-11,91$ & $<0,01$ \\
\hline
\end{tabular}

Analisis Faktor Risiko

Analisis Univariat

Analisis univariat untuk masing-masing faktor risiko penyakit jantung koroner dilakukan untuk mandapatkan odds ratio (OR) (Tabel 5).

Berdasarkan hasil analisis univariat, status merokok, kadar HDL plasma yang rendah, dan hiperhomosisteinemia merupakan faktor risiko yang signifikan terhadap terjadinya penyakit jantung koroner (Tabel 5).

Hiperhomosisteinemia tingkat ringan sampai sedang (> $15 \mu \mathrm{mol} / \mathrm{L}$ ) didapatkan pada 37 penderita penyakit jantung koroner (74\%) dan 18 orang kelompok kontrol
(36\%). Tidak ada seorangpun dengan hiperhomosisteinemia berat (> $100 \mu \mathrm{mo} / \mathrm{L}$ ). Hiperhomosisteinemia ringan sampai sedang meningkatkan risiko penyakit jantung koroner dengan OR 5,06 (95\% Cl: 2,15 - 11,91; $p<0,01)$.

Dari hasil perhitungan dengan menggunakan uji McNemar untuk kasus berpasangan (matched case control), didapatkan OR 4,80 (95\% Cl: 2,11 - 10,85; $p=$ 0,001 ) (Tabel 6). Dari 37 penderita penyakit jantung koroner dengan hiperhomosisteinemia, $8(21,62 \%)$ diantaranya tidak memiliki faktor risiko konvensional penyakit jantung koroner lainnya. 
Tabel 6. Tabel Kontingensi McNemar

\begin{tabular}{ccccc}
\hline & \multicolumn{5}{c}{ Kontrol } & \\
\hline \multirow{3}{*}{ Kasus } & & Hcy $\uparrow$ & Hcy N & Total \\
\cline { 2 - 5 } & Hcy $\uparrow$ & 13 & 24 & 37 \\
\cline { 2 - 5 } & Hcy N & 5 & 8 & 13 \\
\cline { 2 - 5 } & Total & 18 & 32 & 50 \\
\hline
\end{tabular}

Tabel 7. Odds Ratio Faktor-Faktor Risiko Penyakit Jantung Koroner (Stepwise LogisticRegression)

\begin{tabular}{cccccc}
\hline Tertile & tHcy $(\mu \mathrm{mol} / \mathrm{L})$ & Kasus N $(\%)$ & Kontrol N $(\%)$ & OR 95\% Cl & $\mathrm{P}$ \\
\hline 1 & $\leq 10$ & $3(6 \%)$ & $8(16 \%)$ & 1 & \\
\hline 2 & $10,1-15$ & $10(20 \%)$ & $24(48 \%)$ & $1,11(0,20-6,66)$ & 0,893 \\
\hline 3 & $\geq 15,1$ & $37(74 \%)$ & $18(36 \%)$ & $5,48(2,12-13,12)$ & 0,019 \\
\hline
\end{tabular}

Tabel 8. Odds Ratio Faktor-Faktor Risiko Penyakit Jantung Koroner (Stepwise LogisticRegression)

\begin{tabular}{lccccc}
\hline Faktor risiko & Koeff $(\beta)$ & SE & OR & $95 \% \mathrm{Cl}$ & $\mathrm{P}$ \\
\hline Status merokok & 1,12 & 0,108 & 3,06 & $1,89-10,51$ & 0,032 \\
\hline HDL rendah & 1,18 & 0,091 & 3,26 & $1,13-9,36$ & 0,028 \\
\hline Hiperhomosisteinemia & 2,75 & 0,091 & 5,67 & $3,16-17,61$ & $<0,01$ \\
\hline
\end{tabular}

Perbandingan risiko penyakit jantung koroner untuk setiap tertile dari konsentrasi homosistein ditunjukkan dengan jelas dan konsisten dengan kecenderungan peningkatan risiko penyakit jantung koroner searah dengan setiap kenaikan tertile yang lebih tinggi. Hal menunjukkan bahwa konsentrasi tHcy puasa berhubungan kuat, bertingkat dan independen terhadap risiko terjadinya penyakit jantung koroner. Hiperhomosisteinemia puasa dengan nilai cut-off $15 \mu \mathrm{mol} / \mathrm{L}$ meningkatkan risiko penyakit jantung koroner sebesar OR 5,48; 95\% Cl: 12 - 13,12; $p=0,019$ (Tabel 7). Analisis Multivariat

Analisis multivariat dilakukan berdasarkan hasil analisis univariat untuk faktor-faktor risiko yang memiliki OR $<1$ atau OR $>1$, dengan rentang interval kepercayaan 95\% dan nilai $p<0,05$. Analisis multivariat menggunakan regresi logistik dengan penyakit jantung koroner sebagai variabel dependen dan hiperhomosisteinemia, status merokok, hipertensi saat masuk rumah sakit, dan HDL rendah sebagai variabel independen. Hasilnya disimpulkan pada Tabel 8

Setelah dilakukan analisis multivariat didapatkan bahwa hiperhomosisteinemia merupakan faktor risiko independen penting dengan $\mathrm{OR}$ yang tetap signifikan sebesar 5,67 (95\% Cl: 3,16 - 17,61; $p<0,01)$, demikian pula dengan merokok dan HDL rendah $(p<0,05)$.

\section{DISKUSI}

Secara umum bentuk homosistein yang dianggap aterogenik dalam sirkulasi adalah bentuk tereduksinya. Bentuk tereduksi ini hanya 1 persen dari tHcy dalam plasma. Homosistein diduga menyebabkan penyakit jantung koroner melalui berbagai mekanisme, antara lain melalui percepatan aterogenesis dengan perusakan matriks vaskuler, peningkatan injuri oksidatif pada endotelium arteri dan peningkatan proliferasi otot polos vaskuler $(11,12)$.

Hubungan antara hiperhomosisteinemia dengan peningkatan risiko penyakit jantung koroner telah banyak dilaporkan pada penelitian baik retrospektif maupun prospektif $(4,5,6,13)$. Hubungan hiperhomosisteinemia dengan penyakit vaskuler aterotrombosis kemungkinan bersifat kausal, independen terhadap faktor risiko lain, tergantung dosis, dan secara biologis dapat dijelaskan secara ilmiah (12). Hiperhomosisteinemia akan lebih meningkatkan insiden penyakit vaskuler aterotrombosis pada individu dengan risiko merokok dan hipertensi sebelumnya (6).

Penelitian ini merupakan penelitian pertama di Yogyakarta yang memeriksa hubungan antara kadar tHcy dan penyakit jantung koroner. Hasil utama penelitian ini menunjukkan secara bermakna hubungan antara hiperhomosisteinemia puasa ( $>15 \mu \mathrm{mol} / \mathrm{L}$ ) dan risiko penyakit jantung koroner dengan OR 5,67 (95\% Cl: 3,16 $17,61 ; p<0,01)$. Terbukti adanya hubungan yang kuat, independen dan bertingkat antara hiperhomosisteinemia dan penyakit jantung koroner.

Hasil-hasil penelitian sebelumnya yang telah dipublikasikan banyak yang menemukan bukti adanya hubungan yang kuat antara hiperhomosisteinemia dengan penyakit jantung koroner $(4,5,6,9)$.

Clarke et al. (1991), pada suatu penelitian kohort menemukan risiko relatif penyakit jantung koroner pada 
penderita hiperhomosisteinemia sekitar 24 kali dibandingkan kontrol normal (4). Boushey et al. (1995), dari hasil meta-analisis yang meliputi 27 penelitian tentang kaitan hiperhomosisteinemia dengan penyakit jantung koroner menemukan bahwa hiperhomosisteinemia merupakan faktor risiko independen untuk penyakit jantung koroner dengan rasio-odds (OR) setiap peningkatan 5 $\mu \mathrm{mol} / \mathrm{L}$ tHcy adalah sebesar 1,6 untuk pria dan 1,8 untuk wanit, artinya untuk setiap penambahan $5 \mu \mathrm{mol} / \mathrm{L}$ tHcy akan meningkatkan risiko penyakit jantung koroner setara dengan penambahan kolesterol $20 \mathrm{mg} / \mathrm{dl}$ (5). Graham et al. (1997), melaporkan bahwa hiperhomosisteinemia sebagai faktor risiko penyakit jantung koroner sama kuatnya dengan status merokok dan hiperlipidemia (6).

Pada skrining terhadap 75 penderita penyakit aterosklerosis vaskuler prematur ditemukan hampir sepertiga dari seluruh penderita tersebut menderita hiperhomosisteinemia. Hasil penelitian potong lintang dari Framingham Heart Study menemukan hubungan asosiasi yang kuat antara hiperhomosisteinemia dengan penyakit jantung koroner meskipun hiperhomosisteinemia masih dalam derajat ringan (14).

Pada penelitian ini dilakukan pengukuran kadar tHcy pada saat puasa karena pada penelitian-penelitian sebelumnya ditemukan hubungan yang signifikan antara kadar tHcy puasa dengan penyakit jantung koroner prematur (OR 2,0; $P=0,04)$, tetapi sebaliknya hanya terdapat hubungan yang lemah antara kadar tHcy dengan penyakit jantung koroner $(\mathrm{OR} 1,7 ; \mathrm{P}=0,12)$ bila pengukuran homosistein dilakukan setelah pembebanan dengan methionin (14).

Hiperhomosisteinemia mungkin berhubungan dengan faktor-faktor risiko penyakit jantung koroner lainnya seperti merokok, hipertensi, dislipidemia dan hiperglikemia; namun demikian hiperhomosisteinemia tampaknya mempunyai efek yang independen terhadap faktor-faktor risiko tersebut, dan adanya faktor-faktor risiko tersebut secara bersamaan pada satu penderita akan meningkatkan risiko terjadinya penyakit jantung koroner (15). Pendapat ini sesuai dengan hasil pada penelitian ini, dimana berdasarkan analisis multivariat terhadap faktor-faktor risiko lainnya antara lain status merokok, dan kadar HDL plasma yang rendah, didapatkan bahwa hiperhomosisteinemia merupakan faktor risiko independen penting dengan OR sebesar 5,67 (95\% Cl: 3,16 - 17,61; $p<0,01)$.

Pada penelitian ini didapatkan kadar tHcy rata-rata pada kasus sebesar $24,82 \pm 12,62 \mu \mathrm{mol} / \mathrm{L}$ dan pada kontrol sebesar 14,74 $\pm 5,96 \mu \mathrm{mol} / \mathrm{L}$ dengan OR 5,67. Hasil ini agak berbeda dengan hasil yang didapatkan pada penelitian kasus-kontrol yang dilakukan oleh Santosa et al. (2003), di Bandung yang mendapatkan kadar tHcy rata-rata pada kasus sebesar $12,17 \pm 7,45 \mu \mathrm{mol} / \mathrm{L}$ dan kontrol sebesar 9,83 $\pm 3,14 \mu \mathrm{mol} / \mathrm{L}$ dengan OR 2,21 dan penelitian
Widjayakusuma et al., yang mendapatkan kadar tHcy ratarata pada penderita sindroma koroner akut sebesar 18,01 $\mu \mathrm{mol} / \mathrm{L}$. Hal ini mungkin karena faktor genetik, gaya hidup, dan jenis makanan sehari-hari yang berbeda $(16,17)$.

Sebanyak lebih dari 30 penelitian kasus-kontrol yang membandingkan kadar tHcy penderita penyakit jantung koroner dengan kontrol yang sehat, didapatkan penderita penyakit jantung koroner secara bermakna mempunyai kadar tHcy lebih tinggi dibandingkan kontrol sehat dengan rasio-odds antara 1,2 - 10,9. Pada penelitian prosfektif yang meneliti hubungan antara tHcy dengan risiko kematian akibat penyakit jantung koroner didapatkan risiko relatif (RR) sebesar 2,8 untuk kadar tHcy total antara 15-19,9 $\mu \mathrm{mol} / \mathrm{L}$, dan RR meningkat menjadi 4,5 bila kadar tHcy $=20$ $\mu \mathrm{mol} / \mathrm{L}$.

Hasil penelitian kohort prosfektif mendapatkan bahwa kadar tHcy merupakan faktor risiko terbesar untuk terjadinya sindroma koroner akut pada orang yang sudah menderita penyakit jantung koroner sebelumnya. Bukti-bukti yang ditemukan dari penelitian prosfektif ini menunjukkan bahwa homosistein bekerja dengan merangsang terjadinya tromboemboli akut (15). Bukti yang didapat dari penelitian prosfektif ini dapat menunjukkan bahwa hiperhomosisteinemia merupakan faktor risiko kausal terhadap terjadinya penyakit jantung koroner dan bukan sebagai penanda sekunder (secondary marker) adanya penyakit jantung koroner.

Pada penelitian eksperimental yang dilakukan pada hewan dilaporkan adanya peningkatan tekanan darah sebagai respon terhadap hiperhomosisteinemia (18). Buktibukti dari penelitian eksperimental tersebut menunjukkan kemungkinan adanya hubungan kausal antara hiperhomosisteinemia dan peningkatan tekanan darah. Hal ini sesuai dengan hasil penelitian yang dilakukan oleh Lim dan Cassano (2002) yang menyimpulkan bahwa terdapat hubungan yang positif independen antara tHcy dan tekanan darah, yaitu setiap kenaikan $1 \mathrm{SD}(5 \mu \mathrm{mol} / \mathrm{L})$ dihubungkan dengan kenaikan tekanan darah sistolik dan diastolik berurutan sebesar 0,5 dan $0,7 \mathrm{mmHg}$ pada laki-laki dan 0,7 dan $1,2 \mathrm{mmHg}$ pada wanita. Disimpulkan bahwa hiperhomosisteinemia pada wanita akan meningkatkan risiko terjadinya hipertensi sebesar 3 kali (Cl 95\%: 1,70$5,39)$ sedangkan pada laki-laki sebesar 2 kali (Cl 95\%: $0,71-5,14)(18)$.

Penelitian ini memiliki beberapa keterbatasan. Keterbatasan utama adalah data-data yang diperoleh ini berasal dari suatu penelitian kasus-kontrol, dimana kadar tHcy diukur setelah terjadinya sindroma koroner akut, sehingga tidak dapat menentukan apakah kenaikan kadar tHcy ini mendahului penyakit jantung koroner atau sebagai akibat dari penyakit jantung koroner itu sendiri (arah hubungan belum jelas), tetapi hasil meta-analisis yang telah dipublikasikan melaporkan adanya hubungan kausal antara 
hiperhomosisteinemia dengan penyakit jantung koroner $(19,20)$.

Kedua, meskipun seluruh kasus dipilih secara berurutan, namun faktor perancu tidak mungkin sepenuhnya dapat dieliminasi. Penelitian ini relatif kecil (total sampel 100 pasien). Suatu rancangan penelitian yang menggunakan kontrol berbasis populasi dan kontrol berbasis rumah sakit dengan jumlah yang sama, akan dapat meminimalkan bias seleksi bila dibandingkan dengan hanya menggunakan satu sumber kontrol. Pada penderita terutama dengan penyakit yang berat yang dirawat di rumah sakit, tHcy bisa meningkat, kemungkinan dikarenakan kerusakan jaringan (21). Karena alasan tersebut maka penelitian ini menggunakan kontrol rumah sakit, supaya bias hasil penelitian dapat diminimalkan.

\section{KESIMPULAN}

Hiperhomosisteinemia merupakan faktor risiko independen terhadap penyakit jantung koroner dengan OR sebesar 5,67.

Hasil penelitian ini memberi kontribusi bagi penjelasan kasus-kasus penyakit jantung koroner yang terjadi pada penderita tanpa faktor risiko konvensional, yang menyatakan bahwa hiperhomosisteinemia merupakan faktor risiko penyakit jantung koroner.

\section{SARAN}

Pemeriksaan tHcy harus dimasukkan dalam daftar faktor risiko yang harus diperiksa pada saat pencarian faktor risiko.

\section{DAFTAR KEPUSTAKAAN}

1. Irawan B. Patofisiologi Sindrom Koroner Akut dalam Kumpulan Makalah Mini Course Kegawatan Kardiologi. Yogyakarta: Bagian Penyakit Dalam FK UGM-RS DR. Sardjito; 2002; 1-4.

2. Ismail D. Patofisiologi Sindrom Koroner Akut. Dalam Bawazier LA, Alwi I, Syam AF (eds): Prosiding Simposium Pendekatan Holistik Penyakit Kardiovaskular. Jakarta: Pusat Informasi dan Penerbitan Bagian IImu Penyakit Dalam FKUI; 2001; 22-31

3. Makmun LH. Faktor Risiko Penyakit Jantung Koroner. The First Symposium Cardiovascular Respiratory Immunology from Pathogenesis to Clinical Application; 2002; 111-116.

4. Clarke R, Daly L, Robinson K, Naughten E, Cahalane S, Fowler B, Graham I. Hyperhomocysteinemia: An Independent Risk Factor for Vascular Disease. N. Eng J Med. 1991; 324: 1149-1155.

5. Boushey CJ, Bereford SA, Omenn GS, Motulsky AG. A Quantitative Assesment of Plasma Homocysteine as a Risk Factor for Vascular Disease. JAMA. 1995; 274: 1049-1056.

6. Graham IM, Daly LE, Refsum HM. Plasma Homocysteine as a Risk Factor for Vascular Disease. JAMA. 1997; 227: 1775-1781.

7. Christen WG, Ajani UA, Glyn RJ, Hennekens CH. Blood Levels of Homocysteine and Increased Risks of Cardiovascular Disease. Causal or Causal ? . Arch Intern Med. 2000; 160: 422.

8. Wald NJ, Watt HC, Law MR, Hennessy E, McPartlin J, Scott JM. Homocysteine And Ischaemic Heart Disease: Result of A Prospective Study with Implications Regarding Prevention. Arch Intern Med. 1998; 158: 862-867.

9. Rosenson RS, \& Kang DS. Hyperhomocysteinemia, Atherosclerosis, and Venous Thromboembolism. In Up to Date Vol. 10 No. 1 "www.Up to Date. Com" (800) 998-6374; 2002; (781): 237-4788.

10. Schlesselman JJ. Case-Control Studies, Design, Conduct, Analysis. New York: Oxford University Press; 1982

11. Mansoor MA, Svardal AM, Schneede J. Dynamic Relation Between Reduced, Oxidized, and Protein-Bound Homocysteine and Other Thiol Components in Plasma During Methionine Loading in Healthy Men. Clin Chem. 1992; 38:1316-1321.

12. Hankey GJ, Eikelboom JW. Homocysteine and Vascular Disease. The Lancet. 1999; 354: 407-413.

13. Stamler JS, Osborne JA, Jaraji O, Rabbani LE, Mullins M, Singel D, Loscalzo J. Adverse Vascular Effects of Homocysteine are Modulated by Endothelium-Derived Relaxing Factor and Related Oxide of Nitrogen. J Clin Invest 1993; 91:308.

14. Welch GN, Loscalzo J. Homocysteine and Atherothrombosis: Review Article. N Engl J Med. 1998; 338:1042-1050.

15. Booth GL, \& Wang EE. Preventive Health Care. Update: Screening and Management of Hyperhomocysteinemia for Prevention of Coronary Artery Disease Events. CMAJ. 2000; 163 (1) : 21-29.

16. Widjayakusuma B, Mahindra HJ, Maskoen A, Achmad TH. Methylenetetrahydrofolate Reductase Polymorphism and Homocysteine Levels in Indonesian Acute Myovardial Infarction Patients. In: Third International Conference on Homocysteine Metabolism. 2001. 
17. Santosa S, Delima ER, Prahastuti S, Lilyanti Linggajaya W, Prasetya E. Prevalensi Hiperhomosisteinemia pada Penderita Sindroma koroner akut di Rumah Sakit Immanuel Bandung. Dalam: A.W. Sudoyo (Ed) : Naskah Lengkap KOPAPDI- XII 2003 Manado. Jakarta: Acta Medica Indonesiana; 2003; 670 -675.

18. Lim U, Cassano PA. Homocysteine and Blood Pressure in the Third National Health and Nutrition Examination Survey, 1998-1994. Am J Epidemiol. 2002; 156: 1105-1113.

19. Wald NJ, Law M, Morris JK. Homocysteine and Cardiovascular Disease: Evidence on Causality from a Meta-Analysis. BMJ. 2002; 325: 1202-1206.

20. The Homocysteine Studies Collaboration. Homocysteine and Risk of Ischemic Heart Disease and Stroke. JAMA 2002; 288: 2015-2022.

21. Schindler K, Zauner C, Buchmayer H, Fodinger M, Wolfl G, Bieglmayer C, Heinz G, Wilfing A, Horl WH, SunderPlassman G. High Prevalence of Hyperhomocysteinemia in Critically III Patients. Crit Care Med. 2000; 28:991-995. 